\title{
HUBUNGAN TINGKAT PENGETAHUAN ORANG TUA DENGAN KEBERSIHAN GIGI DAN MULUT ANAK DI TK TUNAS BHAKTI MANADO
}

\author{
${ }^{1}$ Triska Yolanda Worang \\ ${ }^{2}$ Damajanti H. C. Pangemanan \\ ${ }^{2}$ Dinar A. Wicaksono \\ ${ }^{1}$ Kandidat Skripsi Program Studi Pendidikan Dokter Gigi Fakultas Kedokteran \\ Universitas Sam Ratulangi Manado \\ ${ }^{2}$ Program Studi Pendidikan Dokter Gigi Fakultas Kedokteran \\ Universitas Sam Ratulangi Manado \\ Email: triskayolandaworang@gmail.com
}

\begin{abstract}
Domain knowledge is very important for the formation of one's actions. Knowledge of parents is very important in the formation of the underlying behaviors that support or do not support the oral hygiene of children. Good oral hygiene will make healthy teeth and surrounding tissues. This study aims to analyze the relationship between the level of knowledge of parent swith achild's dental and oral hygiene in kinder garten Tunas Bhakti Manado. The research used the descriptive analytical study with cross sectional approach. The experiment was conducted in a kinder garten classroom Shoots Bhakti Manado. The sample in this study all children in kinder garten preschool Tunas Bhakti Manado as many as 70 children examined OHI-S and as many as 12 questions questionnaire for the elderly. Sampling technique with a total sampling method.The results of this study indicate that parental knowledge about dental and oral hygiene in either category by $45.7 \%$ with oral hygiene status of children included in the medium category at $65.7 \%$. Based on the results obtained Pearson correlation test $\mathrm{p}$ value of 0.020 ( $\mathrm{p}<0.05$ ). It can be concluded that there is a relationship between the level of knowledge of parents with children's dental and oral hygiene in kindergarten Tunas Bhakti Manado.
\end{abstract}

Keywords: knowledge, OHI-S, preschoolers.

\begin{abstract}
Abstrak: Pengetahuan merupakan domain yang sangat penting untuk terbentuknya tindakan seseorang.Pengetahuan orang tua sangat penting dalam mendasari terbentuknya perilaku yang mendukung atau tidak mendukung kebersihan gigi dan mulut anak. Kebersihan mulut yang baik akan membuat gigi dan jaringan sekitarnya sehat. Penelitian ini bertujuan untuk menganalisis hubungan antara tingkat pengetahuan orang tua dengan kebersihan gigi dan mulut anak di TK Tunas Bhakti Manado.Jenis penelitian yang digunakan yaitu penelitian deskriptif analitik dengan pendekatan cross sectional study.Penelitian dilaksanakan di ruangan kelas TK Tunas Bhakti Manado. Sampel dalam penelitian ini seluruh anak prasekolah di TK Tunas Bhakti Manado sebanyak 70 anak diperiksa OHI-S dan kuesioner sebanyak 12 pertanyaan untuk orang tua. Teknik pengambilan sampel dengan metode total sampling. Hasil penelitian ini menunjukkan bahwa pengetahuan orang tua mengenai kebersihan gigi dan mulut dalam kategori baik sebesar $45,7 \%$ dengan status kebersihan gigi dan mulut anak termasuk dalam kategori sedang sebesar $65,7 \%$. Berdasarkan hasil uji korelasi pearson didapatkan $p$ value $0,020(\mathrm{p}<0,05)$. Dapat disimpulkan bahwa terdapat hubungan antara tingkat pengetahuan orang tua dengan kebersihan gigi dan mulut anak di TK Tunas Bhakti Manado.
\end{abstract}

Kata kunci: pengetahuan, OHI-S, anak prasekolah. 
Pengetahuan merupakan domain yang sangat penting untuk terbentuknya tindakan seseorang. Salah satu yang dapat memengaruhi derajat kesehatan seseorang yaitu perilaku. Domain perilaku kesehatan terbagi atas tiga yaitu pengetahuan, sikap dan tindakan. ${ }^{1}$

Pengetahuan orang tua sangat penting dalam mendasari terbentuknya perilaku yang mendukung atau tidak mendukung kebersihan gigi dan mulut anak. Pengetahuan tersebut dapat diperoleh secara alami maupun secara terencana yaitu melalui proses pendidikan. Orang tua dengan pengetahuan rendah mengenai kebersihan gigi dan mulut merupakan faktor predisposisi dari perilaku yang tidak mendukung kebersihan gigi dan mulut anak. ${ }^{2}$

Gigi bagi seorang anak penting dalam proses pertumbuhan dan perkembangan anak itu sendiri. Fungsi gigi sangat diperlukan dalam masa kanak-kanak yaitu sebagai alat pengunyah, membantu dalam berbicara, keseimbangan wajah, penunjang estetika wajah anak dan khususnya gigi sulung berguna sebagai panduan pertumbuhan gigi permanen. ${ }^{3}$

Anak usia prasekolah adalah anak yang berusia antara 2 sampai 6 tahun dimana pada masa ini anak telah mencapai kematangan dalam berbagai macam fungsi motorik dan diikuti dengan perkembangan intelektual dan sosioemosional. Anak usia dini biasa mengikuti program prasekolah dan kindergarden.

Masalah kesehatan gigi di Indonesia dapat dikatakan cukup tinggi. Berdasarkan Riset Kesehatan Dasar Nasional (Riskesdas) tahun 2007, prevalensi nasional masalah kesehatan gigi dan mulut sebesar 23,5\%. ${ }^{4}$ Hasil Survei Kesehatan Rumah Tangga (SKRT) yang dilaporkan oleh Kementerian Kesehatan Nasional Indonesia Tahun 2010 menunjukkan dari 10 kelompok penyakit terbanyak yang dikeluhkan masyarakat, penyakit gigi dan mulut menduduki peringkat pertama yaitu meliputi 60\% penduduk. $^{5} \quad$ Provinsi Sulawesi Utara merupakan salah satu provinsi yang mempunyai masalah gigi di atas rata - rata nasional yaitu 29,8\%. ${ }^{6}$ Alasan-alasan inilah yang antara lain mendasari penulis untuk melakukan penelitian tentang "Hubungan Tingkat Pengetahuan Orang Tua dengan Kebersihan Gigi dan Mulut Anak di TK Tunas Bhakti Manado.” Penulis juga tertarik memilih lokasi tersebut karena lokasi penelitian mudah dijangkau sehingga mempermudah peneliti untuk melakukan penelitian.

\section{BAHAN DAN METODE}

Penelitian yang dilakukan yaitu penelitian deksriptif analitik dengan menggunakan pendekatan desaincross sectional study. Penelitian ini dilaksanakan di ruangan kelas TK Tunas Bhakti Manado, Jl. Sam Ratulangi, kecamatan Wanea, kota Manado, provinsi Sulawesi Utara, pada bulan Juli Agustus 2014. Sampel dalam penelitian ini yaitu seluruh anak prasekolah di TK Tunas Bhakti Manado sebanyak 70 anak diperiksa OHI-S dan kuesioner sebanyak 12 pertanyaan untuk orang tua dengan teknik pemngambilan sampel yaitu metode total sampling. Data yang diperoleh diolah dengan menggunakan program SPSS versi 21, dan disajikan dalam bentuk tabel distribusi frekuensi.

\section{HASIL PENELITIAN}

Pada penelitian ini, pengetahuan kebersihan gigi dan mulut diperoleh melalui kuesioner yang dibagikan pada orang tua, sedangkan status kebersihan gigi dan mulut dengan pengukuran OHI-S ditentukan melalui penjumlahan Debris Index dan Calculus Index. Data mengenai distribusi orang tua responden berdasarkan pengetahuan kebersihan gigi dan mulut, distribusi responden berdasarkan status pemeriksaan OHI-S, dan distribusi responden berdasarkan uji statistik hubungan pengetahuan kesehatan gigi dan mulut dengan status karies gigi, dapat dilihat pada Tabel 1-3 berikut ini. 
Worang, Pangemanan, Wicaksono; Hubungan Tingkat Pengetahuan Orang Tua...

Tabel 1. Distribusi orang tua responden berdasarkan pengetahuan kebersihan gigi dan mulut

\begin{tabular}{ccc}
\hline Tingkat Pengetahuan & n & \% \\
\hline Baik & 32 & 45,7 \\
Cukup & 29 & 41,4 \\
Kurang & 9 & 12,9 \\
Total & 70 & 100 \\
\hline
\end{tabular}

Tabel 2. Distribusi responden berdasarkan status pemeriksaan $\mathrm{OHI}-\mathrm{S}$

\begin{tabular}{ccl}
\hline OHI-S & n & \% \\
\hline Baik & 19 & 27,2 \\
Sedang & 46 & 65,7 \\
Buruk & 5 & 7,1 \\
Total & 70 & 100 \\
\hline
\end{tabular}

Tabel 3.Distribusi pengetahuan orang tua dengan status kebersihan gigi dan mulut anak

\begin{tabular}{|c|c|c|c|c|c|c|c|c|c|}
\hline \multirow{3}{*}{ Pengetahuan } & \multicolumn{6}{|c|}{ OHI-S } & \multirow{2}{*}{\multicolumn{2}{|c|}{ Total }} & \multirow{3}{*}{ p value } \\
\hline & \multicolumn{2}{|c|}{ Baik } & \multicolumn{2}{|c|}{ Sedang } & \multicolumn{2}{|c|}{ Buruk } & & & \\
\hline & $\mathrm{n}$ & $\%$ & $\mathrm{n}$ & $\%$ & $\mathrm{n}$ & $\%$ & $\mathrm{n}$ & $\%$ & \\
\hline Baik & 12 & 17,10 & 19 & 27,10 & 1 & 1,40 & 32 & 45,70 & \multirow{4}{*}{0,020} \\
\hline Cukup & 6 & 8,60 & 21 & 30 & 2 & 2,90 & 29 & 41,40 & \\
\hline Kurang & 1 & 1,40 & 6 & 8,60 & 2 & 2,90 & 9 & 12,90 & \\
\hline Total & 19 & 27,10 & 46 & 65,70 & 5 & 7,10 & 70 & 100 & \\
\hline
\end{tabular}

\section{BAHASAN}

Hasil penelitian ini menunjukkan bahwa sebagian besar orang tua responden di TK Tunas Bhakti Manado memiliki pengetahuan baik, yaitu sebanyak 32 orang $(45,70 \%)$ dari 70 orang tua responden mendapatkan skor $>27$ atau termasuk dalam kriteria baik pada penilaian kuesioner yang diberikan. Pengetahuan orang tua dapat dipengaruhi oleh beberapa hal, antara lain yaitu usia, pendidikan, status sosial ekonomi, pengalaman, informasi/media massa dan lingkungan. ${ }^{7}$

Berdasarkan hasil pemeriksaan OHI-S pada 70 responden di TK Tunas Bhakti Manado, hasil penelitian menunjukkan persentase status kebersihan gigi dan mulut anak dengan kategori baik sebesar 27,2\%, kategori sedang 65,7\% dan kategori buruk 7,1\%. Dari hasil tersebut juga menunjukkan bahwa rata-rata $O H I-S$ anak di TK Tunas Bhakti Manado adalah 1,65. Berdasarkan kategori $\mathrm{OHI}-\mathrm{S}$ maka nilai tersebut berada dalam kategori sedang.

Penilaian $\mathrm{OHI}-\mathrm{S}$ pada responden berjenis kelamin perempuan menunjukan bahwa 10 responden (27\%) tergolong dalam kategori baik, 25 responden (67\%) tergolong dalam kategori sedang, dan 2 responden (5,4\%) tergolong dalam kategori buruk. Penilaian OHI-S pada responden yang berjenis kelamin laki-laki menunjukan bahwa 9 responden (27\%) tergolong dalam kategori baik, 21 responden (64\%) tergolong dalam kategori sedang dan 3 responden (9\%) tergolong dalam kategori buruk. Anak perempuan lebih baik dalam perilaku menjaga kebersihan gigi dan mulut dibandingkan dengan anak laki-laki. Penelitian yang dilakukan oleh Okemwa pada anak usia 5-17 tahun di Kenya tahun 2010 yang menyatakan bahwa perilaku perawatan kesehatan gigi dan mulut anak perempuan lebih baik daripada anak lakilaki. $^{8}$

Hasil uji statistik didapatkan nilai $p$ value $=0,020(\mathrm{p}<0,05)$ menunjukan bahwa terdapat hubungan antara tingkat pengetahuan orang tua dengan kebersihan gigi dan mulut anak di TK Tunas Bhakti Manado. Hasil penelitian tersebut sama dengan penelitian yang dilakukan oleh Yusuf menyatakan bahwa terdapat hubungan antara tingkat pengetahuan dengan status $\mathrm{OHI}-\mathrm{S}$ pada siswa prasekolah di Sumatera Utara. ${ }^{9}$ 
Tingkat pengetahuan seseorang dapat memengaruhi status kebersihan gigi dan mulut, hal ini ditunjukkan dengan hasil penelitian yang sudah dilakukan.Peran orang tua sangatlah penting untuk meningkatkan status kebersihan gigi dan mulut anak dan merupakan salah satu upaya dalam pemeliharaan kesehatan gigi dan mulut anak. Pendidikan dan pengetahuan orang tua tidak menjamin perilaku sehari-hari anak untuk merawat kebersihan gigi dan mulut mereka. Peran serta dan perhatian dari orang tualah yang dibutuhkan anak usia prasekolah. Salah satu contoh sederhana dalam pemeliharaan kesehatan gigi anak yaitu selalu mengajarkan anak tentang waktu yang tepat dan cara yang baik untuk menggosok gigi serta selalu mengingatkan agar setelah mengonsumsi makanan manis sebaiknya segera berkumur dengan air.

\section{SIMPULAN}

Berdasarkan hasil penelitian yang dilakukan di TK Tunas Bhakti Manado maka dapat disimpulkan sebagai berikut:

1. Pengetahuan orang tua tentang kebersihan gigi dan mulut termasuk dalam kategori baik.

2. Status kebersihan gigi dan mulut anak termasuk dalam kategori sedang.

3. Terdapat hubungan antara tingkat pengetahuan orang tua dengan kebersihan gigi dan mulut anak.

\section{SARAN}

1. Diharapkan pihak sekolah dapat menjalankan program UKGS dan memotivasi anak-anak di TK Tunas Bhakti Manado agar selalu menjaga kebersihan gigi dan mulut.

2. Pengetahuan orang tua di TK Tunas Bhakti Manado umumnya baik, namun pengetahuan yang sudah ada ditingkatkan karena pengetahuan orang tua memengaruhi perilaku anak.

3. Meningkatkan peran orang tua untuk selalu memperhatikan kebersihan gigi dan mulut anak, dan kontrol rutin ke dokter gigi setiap 6 bulan sekali.
4. Diharapkan kepada peneliti lainnya untuk dapat melakukan penelitian yang sama terhadap anak-anak di TK Tunas Bhakti Manado namun dengan cakupan yang lebih beragam, seperti perilaku menyikat gigi, jenis makanan yang dikonsumsi dan kebiasaan yang memungkinkan anak untuk menjaga kebersihan gigi dan mulut.

\section{DAFTAR PUSTAKA}

1. Notoadmodjo S. Kesehatan Masyarakat Ilmu dan Seni. Jakarta: Rineka Cipta. 2011; h.146-50.

2. Eriska. Pengenalan dan Perawatan Kesehatan Gigi Anak Sejak dini. Jurnal kedokteran gigi. Bandung: Universitas Padjadjaran. 2005; h.24.

3. Riskesdas. [online] 2007 [cited 2014 March 10].Availablefrom:http//www.litbang.depke s.go.id/simnas4/day.2/gigi.pdf.

4. Badan Penelitian dan pengembangan Kesehatan. Riset Kesehatan Dasar. Departemen Kesehatan Republik Indonesia; 2008.

5. Irwanasari. Survei Kesehatan Rumah Tangga. Departemen Kesehatan Republik Indonesia; 2008.

6. Laporan data pelayanan kesehatan gigi dan mulut. Dinas Kesehatan Kota Manado. Manado. 2013.

7. Notoadmodjo S. Promosi Kesehatan dan Ilmu Perilaku. Jakarta. Rineka Cipta. 2007; h.77-82.

8. Okemwa KA, Bantangi PM, Rotich JK. The Oral Health Knowledge and Oral Hygiene Practices among Primary School Children age 5-17 Years in Rural Area of Uasin Gishu District, Kenya. East African: Journal of Public Health, 2010. Available from:http//www.ncbi.nlm.nih.gov/pubmed/2 1413602. Cited: August 22, 2014.

9. Yusuf. Hubungan perilaku pemeliharaan kesehatan gigi dan mulut dengan status OHI-S gigi anak prasekolah di kabupaten Langkat Tahun 2004: USU Press. [online]. Available from: http://library.usu.ac.id. (skripsi). h.32-33. 